\section{IRRITABLE BOWEL SYNDROME: \\ PERSONALITY AND HEALTH \\ BEHAVIOURS: A BIOPSYCHOSOCIAL APPROACH}

This paper was presented at the 5th European Psychology Congress, Dublin, Ireland, July 1997

Jean Stanley, MA (RAU)

Anita D Stuart, D.Litt et Phil.

Professor, Department of Psychology

Rand Afrikaans University

H Gertie Pretorius, D. Litt et Phil.

Professor, Department of Psychology

Rand Afrikaans University

\section{ABSTRAK}

Die studie het ten doel gehad om die komplekse aard van die Funksionele Maagderm Versteurings aan te dui deur die interaksie tussen Prikkelbare Dermsindroom en persoonlikheidsaspekte en gesondheidsgedrag ("health behaviour") te bestudeer.

Daar is gebruik gemaak van 'n ex post facto ontwerp om twee groepe vrouens, die een groep met PDS $(N=60)$ en die ander daarsonder $(\mathrm{N}=60)$, ten opsigte van die veranderlikes te vergelyk. Die NEO - Personality Inventory (Revised) is gebruik om die groepe te vergelyk ten opsigte van vyf brel persoonlikheidsaspekte naamlik, Neurotisme, Ekstraversie, Oopheid vir Ervaring, Welgevalligheid en Konsensieusheid. Tweedens is die Health Behaviour Checklist gebruik om gesondheidsgedrag te meet soos aangedui deur die volgende faktore: Gesondheidsinstandhouding en -verbetering, Ongelukbeheer, Verkeer Risikogeneigdheid en Middelrisikogeneigdheid ("Substance").

Die resultate toon aan dat statisties beduidende verskille wel bestaan tussen die groepe ten opsigte van sekere persoonlikheidaspekte (neurotisme, ekstraversie en oopheid vir ervaring) en sekere gesondheidsgedragaspekte (veral gesondheidsinstandhouding en -verbetering en verkeer risikogedrag). Dit wil dus voorkom asof PDS lyers sekere persoonlikheidskenmerke deel wat hul gedrag op so 'n wyse beÔnvloed dat hulle sekere gedrag ten opsigte van die instandhouding en verbetering van hul gesondheid toon.

Laastens word ' $n$ holistiese benadering vir behandeling en terapeutiese intervensies aanbeveel.

\section{ABSTRACT}

The goal of this study was to indicate the complex nature of functional gastrointestinal disorders by studying the interaction between Irritable Bowel Syndrome and person- ality aspects and health behaviour.

An ex post facto design was used to compare two groups of women, the one group with IBS $(N=60)$ and the other without $(N=60)$ in terms of the above mentioned variables. The NEO-Personality Inventory (Revised) was used to compare the groups on five broad aspects of personality i.e. Neuroticism, Extraversion, Openness for Experience, Agreeableness and Conscientiousness. The Health Behaviour Checklist was used to measure health behaviours as indicated by the following factors: Wellness Maintenance and Enhancement, Accident Control, Traffic Risk Taking and Substance Risk Taking.

The results indicate that statistically significant differences do indeed exist between the groups in terms of certain personality aspects (neuroticism, extraversion, openness for experience) and certain health aspects (especially wellness maintenance and enhancement and traffic risk taking). It seems then as if IBS sufferers share certain personality characteristics which influence their behaviour related to the maintenance and enhancement of their health.

Finally, we recommend a holistic approach to treatment and therapeutic interventions.

\section{INTRODUCTION}

Disorders of the gut and their association with psychosocial variables appear to be as old as civilisation itself, yet the precise nature of this mind-body relationship continues to elude those concerned with healing. Consequently, the functional gastrointestinal (Gl) disorders, which are disorders without identifiable structural and organic abnormalities, remain an area of gastroenterology that is poorly understood and whose causes are unknown (Drossman, 1994:1-17).

The high prevalence of the functional GI disorders, particularly in developed societies (both east and west) is cause for concern. Relevant studies indicate that approximately one in every four persons is afflicted with one or more functional Gl symptoms, although most do not seek medical care. Furthermore, the functional Gl disorders account for half of all referrals to gastroenterologists, of which the Irritable Bowel Syndrome (IBS) is the most common, comprising one fifth to a half of these referrals. It appears that women are more likely to report and seek treatment for more functional Gl symptoms, as are younger persons. Although IBS is classified as a chronic or long-term condition and can cause enormous discomfort and stress, there is no evidence that it predisposes the person to other diseases or that it is life threatening (Drossman, 1994:1-17; Prior, 1994:327-329). The significant incidence of the functional Gl disorders combined with insufficient knowledge about etiology, invasive diagnostic procedures and ineffective treatment modalities, are the source of enormous frustration for both doctors and patients alike. Not only are state costs high in terms of medical care but also, as Els, Gajiano, Grundling, Van Zyl 
and Joubert (1995:1368) point out, the morbidity of IBS is responsible for work absenteeism second only to the common cold.

Whilst previous paradigms have offered either purely biological or purely psychological explanations, the emerging biopsychosocial paradigm forges a middle way between these two extremes by proposing that genetics or acquired biochemical or structural disorders are modulated by psychosocial stimuli. This shift away from the biomedical model as the dominant model of disease towards a more holistic or systems view, not only offers a clearer concept of the nature of functional disease, but represents a more humane approach that takes greater cognisance of the complexity of whole-person functioning (Drossman, 1994:1; Engel, 1977:129). Significantly, the broadening of health to include social, cultural, psychological and environmental concerns has fostered a multidisciplinary team approach that has in turn, re-opened up a niche for psychologists as collaborators in the biopsychosocial interface in medicine (Alcorn, 1991:325). Accordingly, in describing the functional $\mathrm{Gl}$ disorders as one of the greatest challenges posed to behavioural medicine, Whitehead and Bosmajian (1982:972) emphasise the substantial and currently unmet need for psychologically informed services.

As good health is as much a state of mind as a condition of the body (Thorensen \& Eagleston, 1985:15-16), the personality-health relationship represents the ideal interface for the study of the mind-body link. The past two decades have seen a resurgence in interest in this relationship based on accumulating evidence suggesting that personality may influence health and disease, and that the study of personality as it relates to health has explanatory and perhaps even predictive value (Smith \& Williams, 1992:395).

The advances in biomedicine and improved control of infectious agents has shifted the focus of medicine to a class of diseases where risk factors are linked to behavjours of the people or characteristics of their situation. The fact that these slow-acting chronic diseases now account for more than fifty percent of health problems in developed and industrialised societies, implicates the continuing influence of lifestyle or health behaviours in determining patterns of health and illness. Factors like poor diet, lack of exercise, cigarette smoking, drug and alcohol abuse, car accidents and the long-term results of stress are linked to cancer, hypertension, diabetes, arthritis and the functional Gl disorders like IBS.

Furthermore, the need for management rather than cure in the chronic illnesses has highlighted the central role of individual responsibility and choice and focused increased attention on prevention and health promotion efforts. This has in turn fostered a heightened receptivity for psychological interventions directed at maximising behavioural health (Alcorn, 1991:325-341; Matzarro, 1980:807; Thorensen \& Eaglestone, 1985:15). In particular, there is consensus amongst counselling psychologists that their sub-speciality of applied psychology with its unique focus on the whole person in context over time has a significant contribution to make in this arena. Their emphasis on prevention, development and psycho-education suggests a major opportunity for impacting on the health of society through the development of appropriate interventions tajlored to the individual and designed for managing and preventing problems involving health and behaviour (Alcorn, 1991:325-341; Pomerleau, 1982:1030-1039).

\section{DEFINITION AND DEVELOPMENT OF IBS}

In the absence of physiologic factors, the functional Gl disorders must be diagnosed by their symptoms alone. As part of an international working panel investigating the functional Gl disorders, Drossman (1994:1-17) believes it is clinically important to categorise symptoms so as to facilitate diagnosis and treatment. These specialists adhere to the recently revised ROME diagnostic criteria which outline a wide range of symptoms characterised in terms of six different regions of the Gl tract, viz. the esophageal, gastroduodenal, bowel, functional abdominal pain, biliary and anorectal. Not only may symptoms overlap, but the high incidence of the functional GI disorders mean that it is likely that they will co-exist with other diseases.

A functional bowel disorder is a functional $\mathrm{G}$ l disorder with symptoms such as abdominal pain, bloating or distension and various symptoms of disordered defecation that are attributable to the mid or lower gastrointestinal tract. Drossman (1994:1-17) describes Irritable Bowel Syndrome as the prototype functional bowel disorder which has been known by a multitude of names including "spastic colitis", "irritable colon", mucous colitis" and "nervous stomach". However, since the syndrome does not involve any demonstrable inflammatory process, the suffix "-itis" is misleading and the term Irritable Bowel Syndrome has become a more appropriate standard (Walker, RoyByrne, Katon, Li, Amos \& Jiranek, 1990:1656). IBS can then be defined as "Continuous or recurrent symptoms of: abdominal pain relieved by defecation, or associated with change in frequency or consistency of stool, and/or disturbed defecation (two or more of): looser stools frequency, altered stool form (hard or loose $\backslash$ watery), altered stool passage (straining or urgency, feeling of incomplete evacuation), passage of mucus, usually with bloating or feeling of abdominal distension" (Walker, Roy-Byrne \& Katon, 1990: 565).

In challenging the exclusive emphasis on one domain of functioning such as the biological, to the neglect of other domains such as the psychological and social, the biopsychosocial model conceptualises the development of IBS as a multi-casual complex process whereby both physiological and psychological processes are operative. Drossman (1994) and other gastroenterologists working within the biopsychosocial model propose that psychoso- 
cial mechanisms (like the influence of culture, family, personality, life stressors, social support and coping mechanisms) act as modulators of biological states. These modulating or mediating factors shape symptom severity, medication use and illness behaviour and ultimately determine the individual's so called Health Related Quality Of Life (HRQOL). However, given the complex relationships between the various domains of functioning, and the lack of clarity regarding pathways and mechanisms linking psychosocial factors to disease and illness, it is likely that these connections are nonlinear, multifactorial and change over time (Temoshok, 1990).

\section{DIAGRAM 1.}

The development of IBS(Drossman, 1994)

\section{The development of IBS}

\section{PREDISPOSING}

\section{PSYCHOSOCIAL} MODIFIERS

- Genetic

- Environment

$$
\begin{aligned}
& \text { - Culture/family - Social support } \\
& \text { - Psychological - Coping } \\
& \text { status } \\
& \text { - Personality - Life stress } \\
& \text { - Health behaviours }
\end{aligned}
$$

Early life $\longrightarrow \begin{gathered}\text { Functional } \\ \text { Gl disorders }\end{gathered} \begin{aligned} & \text { Outcome } \\ & \text { HRQOL }\end{aligned}$

- Well-being

- Daily function

- Health care use

- Symptoms

\section{Biological Factors}

Numerous authors variously proposed that the IBS is the result of disordered gut motility, central nervous system dysfunction, immunologic hypersensitivity and mast cell dysfunction as well as possible chemical imbalances in the autonomic innervation of the gut (Drossman, 1983:489491, 1994; Els et al. 1995:1368-1372). However, as the ability to identify physiological changes remains limited, it is also likely that symptoms may be due to altered perception which in turn determines how these are acted upon. Essentially, it remains unclear to what extent IBS symptoms represent normal perception of abnormal function or abnormal perception of normal function (Drossman, 1994; Whitehead, 1988). What is clear, is that bowel symptoms (or their absence) do not always correlate with the presence or absence of pathophysiological abnormalities, and that there are a variety of psychosocial symptoms brought to doctors.

\section{Psychosocial Factors}

In terms of the psychosocial modifiers, Drossman (1994) discusses the relevance of three general findings.

- Psychosocial stress exacerbates GI symptoms. It is known that stressful stimuli alter both large and small gut motility, but seems to do so to a greater extent in those with the functional Gl disorders. Not only do stressful life events seem to frequently precede the onset and reporting of IBS symptoms, but IBS patients differ from the healthy by having greater symptomatic and physiological responses to various stressors (Drossman \& Thompson, 1992:1009).

\section{- Psychological disturbances modify the experience}

of illness. It appears that those who report functional Gl disorders tend to show greater psychological disturbance than do otherwise healthy controls or other medical comparison groups. Psychosocial factors such as early childhood socialisation of illness behaviour, as well as trauma such as physical, emotional and sexual abuse, have been shown to be associated with IBS and tend to contribute to poorer adjustment and increased help-seeking behaviour (Drossman, 1994; Prior, 1994:327-332). In addition, IBS patients show elevated levels of anxiety, neuroticism (or emotionality), depression and somatisation, whilst IBS non-consulters like normal persons, do not. However, it is the opinion of some researchers that these psychological disturbances may not be a unique feature of IBS, but instead indicative of illness behaviour and illness reporting in general (Drossman \& Thompson, 1992:10091016; Keltijangas-Jarvinen, 1989:325-331).

- There are certain psychosocial consequences. These include effects on general well-being, daily functioning, concerns related to symptom control as well as implications of the illness in terms of future functioning both at home and at work. Drossman (1994) introduces the broad concept of Health 'Related Quality Of Life (HRQOL) to describe the patients standing in terms of perceptions, illness experience and functional status relative to the illness. Measurement of the concept differs from an objective disease assessment from the physician's point of view in that it includes the individual's subjective perception of psychosocial and disease related factors. The reciprocal relationship between HRQOL and the severity of the disorder is emphasised.

\section{THE ROLE OF PERSONALITY AND HEALTH BEHAVIOURS}

\section{Personality traits}

Since ancient times there have been claims that personality dispositions may play a role in influencing health and illness, as people have different temperaments, face different challenges and employ different coping skills. In this respect, the shift to whole person care involves recognising the autonomy or uniqueness of the individual system and how this uniqueness influences the manifestation of illness. This autonomy or uniqueness, commonly termed personality, is defined by Allport (in Kobasa, 1990: 25) as "the dynamic organisation within the individual of those psychophysical systems that determine his characteristic behaviour and thought". The term dynamic organisation emphasises the interacting and integrating patterns of the various aspects of the personality system and implies that disturbance in any one part will reverberate through and affect other parts of the personality. Essentially, the notion 
that personality characteristics might influence vulnerability to illness and illness progression is therefore a viable one, despite the fact that little is known about the specific linkages or patterns involved.

Friedman (1991:1-10) suggests that there are two main paths through which personality might influence health and illness: The internal physiological route and the external behavioural route. The internal route involves examining the role of stress, or more broadly speaking, emotion, which is typically regarded as the mediator of personalityillness relationships (Lazarus, 1990:97-120). Excessive stress is believed to contribute significantly to the origins and development of most illnesses, manifesting through the person's initial imbalance and subsequently being channelled through the individual's particular personality configuration and constitutional vulnerability to give rise to specific disorders (Suls \& Rittenhouse, 1990:38-64). In recent research Friedman (1991:1-11) suggests that rather than specific personalities giving rise to specific illnesses, there appears to be a general personality type that, together with other factors, plays a causal role in the onset of different diseases. Whilst Friedman (1991) refer to this as a 'disease-prone' personality, Stone and Costa (1990:178-200) argue that the more appropriate term is 'distress-prone' personality.

Personologists have traditionally proposed a whole range of lists and taxonomies of factors and variables to account for the complexity of human nature, and the centuries old debate over which are the most appropriate fundamental building blocks of personality continues into the present day (McAdams, 1995:365). In the light of this, it is significant that, the broad categories of individual differences known as traits, have recently made a comeback based on the research suggesting they reflect real differences in behaviour and personality and are fairly accurate predictors of behaviour (Dreary \& Mathews, 1993:299; McAdams, 1996:374). However, the lack of a unified framework of personality, together with the failure to take full advantage of more recent conceptual and methodological developments within the field of personality, has been regarded by some as a stumbling block to significant research progress (Marshall, Wortman, Vickers, Kusulas \& Hervig, 1994:278; Smith \& Williams, 1992:395).

To some extent this has been overcome by the five-factor model (FFM) of personality, which has proved robust across different groups of subjects, item pools, instruments and methods of analysis, as well as across different languages and cultures (Halverson, Kohnstamm \& Martin, 1994). Whilst the specific number and interpretation of the five factors remains controversial, the model is commonly represented by Costa and McCrae's (1987:299-316) version of Neuroticism (or Emotional Stability), Extraversion, Openness to Experience, Agreeableness and Conscientiousness, which is the only one to have thus far been operationalised in the form of the NEO-Personality Inventory (Digman, 1990:417; Dreary \& Matthews, 1993:299; McCrae \& John, 1992:175). Apart from providing a common language for clinicians and an efficient means of integrating the plethora of personality constructs and measuring instruments, Costa and McCrae (1987:299-316) refer to the utility of the five-factor model in various applied fields, particularly the clinical and counselling areas.

\section{Health Behaviours}

Personality can also affect health through what Friedman (1991) describes as the external Dehavioural route. Research in this area suggests that certain personality traits or styles may confer greater illness risk by exposing the person to inherently riskier circumstances. The assumption is that certain personality types create stressful lives by making certain kinds of events more likely to happen. This can include unhealthy or risky behaviour, exposure to violence, friendship patterns and co-operation with medical treatment.

One particular set of behavioural factors that is attracting increasing research attention is health habits or health behaviours. Kasl and Cobb (in Vickers et al. 1990: 377) defines health behaviours as "actions undertaken to maintain or improve health". Past attempts to understand health behaviour have focused mainly in single heaith practices such as smoking or exercise, despite the fact that health behaviours tend to occur in distinct clusters. Health-related behaviours that tend to cluster together are smoking and drinking alcohol, and eating a healthy diet and using seat belts. Given that the overall patterns of health behaviours predict morbidity and mortality better than single behaviours, it can be maintained that an understanding of the psychosocial antecedents of these health behaviour patterns could lead to better models to explain the development of disease and illness and to better interventions to minimise health problems (Belloc \& Breslow, 1972:409421).

Evidence indicating that health behaviours occur in dimensions that can be reliably measured was provided by Vickers et al. (1990:377-401) who identified the four dimensions of health behaviour: 1) wellness behaviours (e.g. exercise and good diet), 2) accident control (e.g. knowing first aid), 3) traffic risk taking (e.g. speeding, taking risks as a pedestrian) and 4) substance risk taking (e.g. alcohol consumption, smoking). Although any given behaviour may be influenced by motives specific to that behaviour or by the constraints of the specific situation, aggregate behaviour patterns, including health behaviour patterns, should be predicted best by correspondingly broad personality constructs (Funder, 1991:31).

Despite evidence that personality is a potentially important predictor of health behaviours, only one other study has combined comprehensive measurement models for both personality and health behaviour domains. Using Costa and McCrae's FFM and their own Health Behaviour Checklist (HBC) Vickers, Conway and Hervig (1990:377401), provided evidence suggesting that broad personality traits may be important predictors of health behaviour patterns. Findings from the research of Booth-Kewley and Vickers (1994:281) point to possible expansions and 
refinements of the conceptual frameworks guiding health behaviour research. Furthermore, the change in perspective on health behaviours suggested by the findings could have significant implications for applied health behaviour research. Given the stability of personality in adulthood (Costa \& McCrae, 1987:299) and our limited knowledge of the determinants of personality change, any causal sequence from personality to health behaviours would represent a significant barrier to changing these behaviours. With further study, however, these barriers might be overcome by designing behaviour change programs that take personality predispositions into account.

\section{THE CURRENT RESEARCH}

In rising to the challenge presented by the functional GI disorders, this particular study on IBS, health behaviours and personality adopts a salutogenic rather than a pathogenic perspective, thereby focusing on the maintenance and enhancement of health or wellness over and above the prevention and treatment of illness (Strumpfer, $1990: 265)$. In this regard, it appears that past research has underestimated the role of personality as an influence on health behaviour, probably because of the failure to consider broad health behaviour dimensions as criteria, and because of the omission of important personality dimensions.

\section{Aims and objectives of the study}

In the light of the scanty as well as controversial and contradictory data on the personality-health relationship we were interested in determining whether certain health behaviours and certain personality traits can be associated with IBS. Understanding the impact of certain lifestyles and personality and traits may be of enormous practical and therapeutic value for IBS sufferers. The value lies not only in terms of reducing and perhaps eliminating costly and invasive diagnostic procedures, but also through enhancing of treatment strategies. On a broader level this study aims to take advantage of recent conceptual changes occurring within the behavioural health arena in order to improve our understanding of whole-person care and reaffirm psychology's role in the bio-psycho-social approach to whole-person care.

By building on the recent conceptual developments in the medical, health and personality fields, the specific aim of this study was to examine the interaction between five personality domains and four health behaviour domains in relation to Irritable Bowel Syndrome.

\section{METHODOLOGY}

As the collection and analysis of data occurred after IBS was diagnosed, the study used an ex post facto design to compare two groups of subjects with regard to nine variables as measured by two questionnaires.

\section{Subjects}

The study was based on results from $(n=60)$ IBS female patients who were selected as referrals from general physicians and gastroenterologists around the Witwatersrand area. IBS patients were only selected into the IBS subject group on receipt of signed certification from a doctor or specialist. Non-IBS female subjects were selected through a "pool" of friends and associates. The method proved to be highly successful and produced a randomised control group.

In order to ensure that the two groups were kept as homogenous as possible, the extraneous variables of age, gender and race were controlled for. A lower age limit of 18 years was set to ensure that personality was appropriately formed, whilst female subjects were used as women report more commonly to doctors. Using white subjects controlled for race. The latter decision was based on the existence of possible differences in terms of the cultural interpretations of health and illness. In addition, a history of unequal access to health-care facilities may be a factor that has biased certain sectors of the population to seek health-care for certain kinds of disorders and not for others.

\section{Measuring Instruments}

Two questionnaires and an IBS selection instrument were administered to all the IBS and non-IBS subjects.

Drossman, Zhiming, Toner, Diamant, Creed, Thompson, Read, Babbs, Barreiro, Bank, Whitehead, Schuster \& Guthrie's (1995:986-995) Functional Bowel Disorder Severity Index (FBDSI) was used for the diagnostic evaluation of IBS and to delineate mild, moderate and severe cases. The FBDSI allows clinicians to determine the amount and frequency of abdominal pain experienced by a patient, as well as its interference with the patient's daily activities.

By comparing FBDSI scores to the degree of disability (interference with daily activity),construct validity was determined. A significant association was found (KruskalWallis test; Chi-square $=43.6$; degrees of freedom $=4 ; \mathrm{P}$ $=0.0001$ ).

The NEO - Personality Inventory (Revised) by Costa and McCrae, (1992:5-13) looks at five broad dimensions of personality and is a 181-item personality questionnaire answered on a five-point scale from "strongly disagree" to "strongly agree". The inventory measures five broad domains of personality, each of which are broken down into six facets or more discrete traits.

1. Neuroticism describes a person's stand ing in terms of emotional adjustment or stability. It is not a measure of psychopathology but merely refers to a gen eral tendency to experi ence negative affects such as fear, sadness, guilt, anger and disgust.

2. Extraversion refers to the disposition towards positive emotions, sociability and high activity.

3. Openness to Experience is a receptive orientation towards varied experiences and ideas.

4. Agreeableness describes the inclination towards 
interpersonal trust and consideration of others.

5. Conscientiousness describes the tendency towards persistence, industrious ness and organisation.

The NEO-PI $\otimes$ scales and sub-scales have adequate consistency, test-retest reliability, content validity and construct validity (Costa \& McCrae, 1992:5-13). An additional advantage of using this personality measure was that it contains no health-related items and so avoided the problem of content contamination.

The Health Behaviour Checklist (Vickers et al. 1990:377399) consists of 40 items, of which 26 are used to assess four factor-analytically-defined health behaviour dimensions, with 14 additional filler items. Subjects had to indicate how well each item described her typical behaviour using a 5-point Likert scale ranging from 1 "strongly disagree" to 5, "strongly agree". The HBC measures four replicable factors:

1. The Wellness Maintenance and Enhancement dimension consists of items such as "I exercise to stay healthy".

2. The Accident Control dimension: includes items like "I fix broken things around my home straight away."

3. The Traffic Risk Taking dimension consists of items such as "I drive after drinking" whilst the

4. Substance Risk Taking dimension includes items like "I do not drink".

\section{Procedure}

Both groups of subjects were recruited during 1996. The subjects were targeted through an extensive marketing campaign that involved meeting with general practitioners and specialists, dieticians as well as various pharmaceutical companies. Articles informing the public about the Centre and the research project and calling volunteers were released in an Afrikaans newspaper and an Afrikaans women's magazine. A feature on the Centre was also reviewed on SABC TV's "Health Watch" programme.

Once subjects were medically cleared as having IBS, and were willing to participate in the research, they were invited to participate in a semi-structured interview and to complete the necessary battery of questionnaires. After the results were interpreted and profiles drawn for each individual, they were entitled to six free counselling sessions.

\section{RESULTS AND DISCUSSION}

Hotellings T-square test and the Student's t-test were used to ascertain the significance of the differences between the two groups. A stepwise discriminant analysis was also performed to ascertain which of the 10 variables provided the greatest contribution to the differences between the IBS and non-IBS groups.

TABLE 1: $\quad$ Significance of differences between IBS and non-IBS groups with regard to five NEO PI-R sub scales.

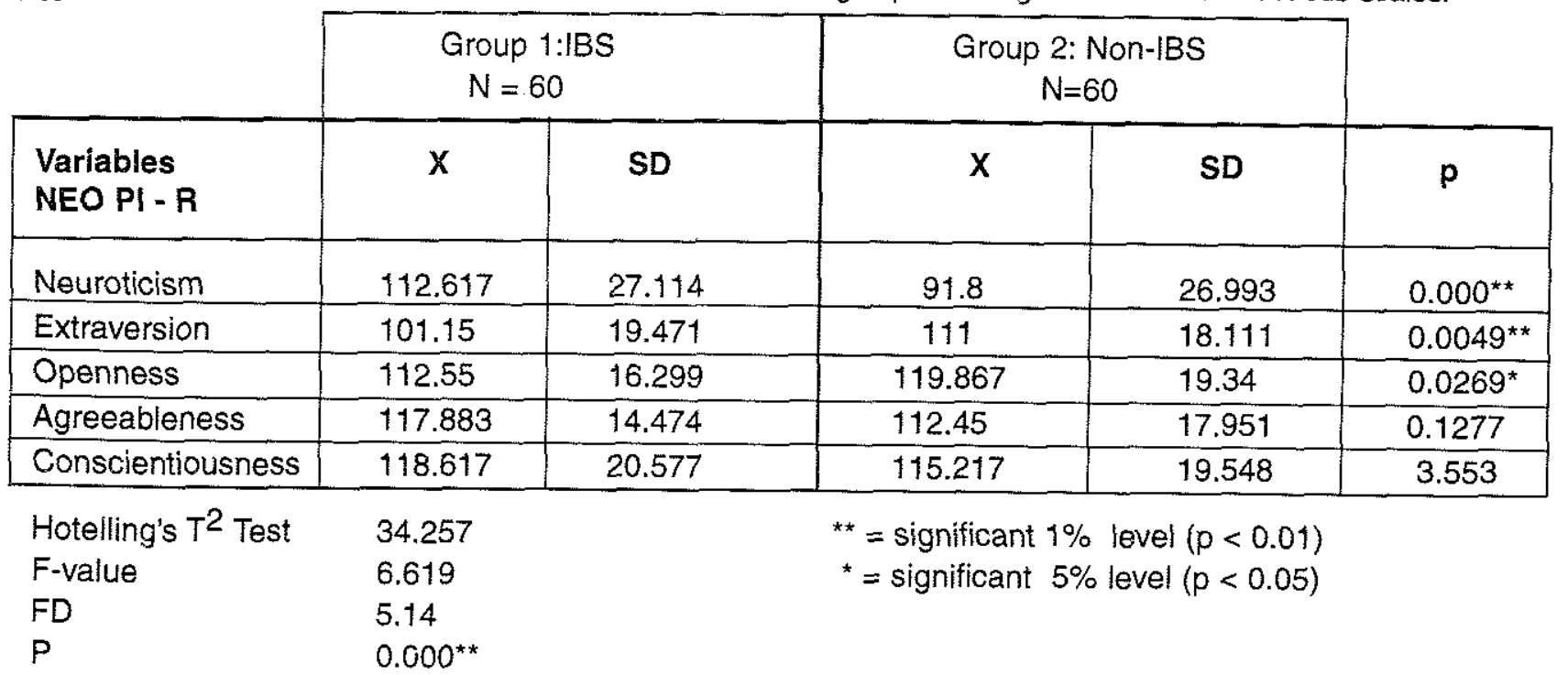

Vickers et al. (1990:377-399) report modest intercorrelations amongst the four health behaviour dimensions, with correlations averages across four samples ranging from 0.10 to 0.48 . Adequate coefficient alpha internal consistencies of 0.65 or greater were obtained for all scales except the Substance Risk Taking Scale, which had an average alpha of 0.55 . (Vickers et al. (1990:377) undertook an extensive study to demonstrate the multidimensionality of health behaviours and the robustness of the proposed health behaviours dimensions.)
Hotelling's T2 test was statistically significant. The Student's t-test showed significant differences between the two groups in terms of Neuroticism, Extraversion and Openness to Experience. The IBS group's highly significant score on Neuroticism supports the large body of evidence that high scorers on this dimension are more susceptible to psychological distress. Persons sufferings from IBS are thus more prone to irrational ideas, less able to control their impulses and tend to cope more poorly with stress. As Neuroticism is related to physical complaints 
and health-care utilisation, it appears that people high in this dimension, such as the IBS sufferers in this study, are more vigilant about bodily changes, more apt to interpret unusual sensations as signs of illness and more likely to worry about possible diseases.

The IBS group scored significantly lower on the Extraversion/Introversion dimension. This suggests that these people prefer to do many things alone or in small groups. They avoid large, noisy gatherings and tend to be quiet and reserved in social interactions. The inverse of Extraversion is emotional inhibition. Research in this area clearly demonstrates that habitually inhibiting emotions can pose threat to physical and emotional health. The combination of the Introversion and high Neuroticism of the IBS group in this study suggests reliance on a neurotic style of coping that is characterised by avoidant or passive reactions where emotions are suppressed and the self is blamed.

The significant difference between the groups in terms of Openness to Experience dimension suggests that the IBS group is more conventional in behaviour and conservative in outlook. They prefer the familiar to the novel and find change difficult.

In terms of psychotherapeutic treatment, the high Neuroticism scores suggests a psychotherapeutic treatment that focuses on more generic difficulties such as the regulation of mood or anxiety and the setting of clear and realistic treatment goals. The lower Openness to Experience suggests more conventional interventions like the behavioural and cognitive therapies.
As can be seen from the table, Hotellings T2-test was again statistically significant. There was a highly significant difference between the two groups in terms of the Additional Items sub-scale, with the IBS group scoring much higher than the control group. As IBS sufferers already appear high in Neuroticism and cope more poorly with stress than most, it is possible that this in turn affects their daily health behaviour practices.

A stepwise discriminant analysis indicated that four factors contributed to the differentiation between the two criterion groups, namely, in order of size of contribution:
1) Additional ltems
2) NEO-Neuroticism
3) Weliness Maintenance and Enhancement behaviours
4) Traffic Risk behaviours.

\begin{abstract}
Wellness Maintenance and Enhancement (WME) behaviours accounted for the second highest contribution to the variance between the scores in terms of the $\mathrm{HBC}$, followed by Traficic Risk behaviours. The fact that the IBS groups scored higher on WME behaviours suggests that their concern with preventative behaviours may accord with their attention to bodily functions and health care. The higher score of the IBS group on the Traffic Risk taking behaviours indicates that this group takes far higher risks in terms of their traffic behaviour. A possible hypothesis is that this could be related to their high score on Neuroticism, which implies low impulse control and inability to cope with stress.
\end{abstract}

TABLE 2: $\quad$ Significance of differences between IBS and non-IBS groups with regard to five Health Behaviour Checklist (HBC) sub-scales.

\begin{tabular}{|c|c|c|c|c|c|}
\hline \multirow[b]{2}{*}{$\begin{array}{l}\text { Variables } \\
\text { HBC }\end{array}$} & \multicolumn{2}{|c|}{$\begin{array}{c}\text { Group 1:IBS } \\
N=60\end{array}$} & \multicolumn{2}{|c|}{$\begin{array}{c}\text { Group 2: Non-IBS } \\
\qquad N=60\end{array}$} & \multirow[b]{2}{*}{$p$} \\
\hline & $x$ & SD & $\mathrm{X}$ & SD & \\
\hline$H D D$ & 24.45 & 15.074 & 42.883 & 5.231 & $0.000^{\star *}$ \\
\hline WME & 34.683 & 4.645 & 32.6 & 6.228 & $0.04^{* *}$ \\
\hline$A C C$ & 19.617 & 4.614 & 18.583 & 4.048 & 0.1949 \\
\hline TRAFFIC & 118.967 & 4.146 & 19.4 & 3.747 & 0.549 \\
\hline SUBSTANCE & 114.217 & 3.47 & 13.033 & 3.641 & 0.071 \\
\hline $\begin{array}{l}\text { Hotelling's } \mathrm{T}^{2} \text { Test } \\
\text { F-value }\end{array}$ & $\begin{array}{c}96.726 \\
18.689\end{array}$ & & $\begin{array}{l}\text { significan } \\
\text { significan }\end{array}$ & $\begin{array}{l}(p<c \\
1 p<c\end{array}$ & \\
\hline
\end{tabular}

$\begin{array}{ll}\text { FD } & 5.114 \\ P & 0.000^{*}\end{array}$


TABLE 3: The variables that were extracted and their Wilks' coefficient lambda.

\begin{tabular}{|l|c|c|c|c|}
\cline { 2 - 5 } & Variables & $\begin{array}{c}\text { Approximated } \\
\text { F-Value to enter }\end{array}$ & $\begin{array}{c}\text { U-statistic or Wilks' } \\
\text { coefficient lambda }\end{array}$ & $\begin{array}{c}\text { Approximated } \\
\text { F-statistic } \\
\text { D.F. }\end{array}$ \\
\hline 1. & ADD & 80.08 & 0.5957260 & 1.118 \\
\hline 2. & NEO $-\mathrm{N}$ & 10.59 & 0.5462635 & 2.117 \\
\hline 3. & WME & 5.5 & 0.5215387 & 3.116 \\
\hline 4. & TRAFFIC & 5.13 & 0.4992726 & 4.115 \\
\hline
\end{tabular}

\section{CONCLUSION}

This study provides empirical evidence to support the theory that the development and course of functional Gl disorders, as many other disorders, are in constant interaction with several dimensions such as personality and health behaviours.

This has implications for the treatment and counselling of people with functional $\mathrm{Gl}$ disorders. In order to provide a professional, efficient and effective service to people we suggest a holistic counselling and treatment approach, utilising knowledge of the role of personality and health behaviours in psychosomatic problems such as Irritable Bowel Syndrome.

\section{REFERENCES}

ALCORN, JD 1991: Counselling Psychology and Health Applications. The Counselling Psychologist, 19(3): 325341.

BELLOC, NB \& BRESLOW, L 1972: Relationship of physical Health Status and Health Practices. Preventive Medicine, 1: $409-421$

BOOTH-KEWLEY, S \& VICKERS, RR 1994: Associations between Major Domains of Personality and Health Behaviour. Journal of Personality, 62(3): 281-298.

COSTA, PT Jr \& MCCRAE, RR 1987: Neuroticism, somatic complaints, and disease: Is the bark worse than the bite? Journal of Personality, 55: 299-316.

COSTA, PT Jr \& MCCRAE, RR 1992: Normal Personality Assessment in Clinical practice: The NEO Personality Inventory. Psychological Assessment, 4(1): 5-13.

DIGMAN, JM 1990: Personality structure: Emergence of the Five-Factor Model. Annual Review of Psychology, 41: 417 - 440 .
DREARY, IJ \& MATTHEWS, G 1993: Personality traits are alive and well. The Psychologist, July: $299-311$.

DROSSMAN, DA \& THOMPSON, WG 1992: The Irritable Bowel Syndrome: Review and a Graduated Multicomponent Treatment Approach. Annals Of Internal Medicine, 116(12): 1009 - 1016.

DROSSMAN, DA ed. 1994: The Functional gastrointestinal Disorders: Diagnosis, Pathophysiology, and Treatment - A Multinational Consensus. Boston: Little, Brown \& Co.

DROSSMAN, DA 1983: Patients with the Irritable Bowel Syndrome: Seeing the Forest for the Trees (or How Not To Bark Up The Wrong Tree). J. Clin. Gastroenterology, 5: $489-492$.

DROSSMAN, DA; ZHIMING, LI; TONER, BB; DIAMANT, NE; CREED, FH; THOMPSON, D; READ, NW; BABBS, C; BARREIRO, M; BANK, L; WHITEHEAD, WE; SCHUSTER, M \& GUTHRIE, EA 1995: Functional Bowel Disorders: A Multicentre Comparison of Health Status and Development of an Illness Severity Index. Digestive Diseases and Science, 40(5): 986 - 995.

ELS, C; GAJIANO, CA; GRUNDLING, H DE K; VAN ZYL, $J$ \& JOUBERT, G 1995: A Study of Psychiatric Illness in Patients With Irritable Bowel Syndrome. South African Medical Journal, 85(12):1368 - 1372.

ENGEL, GL 1977: The need for a New Medical Model: A Challenge for Biomedicine. Science, 196(4286): 129 . 196.

FRIEDMAN, HS 1991: The Self-healing personality: Why some people achieve health and others succumb to illness. New York: Henry Holt \& Co.

FUNDER, DC 1991: Global traits: A neo-Allportian approach to personality. Psychological Science, 2: 31 39.

HALVERSON, CF; KOHNSTAMM, GA \& MARTIN, RP 1994: The developing structure of temperament and personality from infancy to adulthood. Hillsdale: Lawrence 
KELTIKANGAS-JARVINEN, L 1989: 'Psychosomatic Personality' - A Personality Constellation or an Illnessrelated Reaction? British Journal of Medical Psychology, 62: $325-331$.

KOBASA, SC 1990: Lessons from history: How to find the person in health psychology. (In: Friedman, HS ed. 1990: Personality and disease. New York: John Wiley \& Sons.)

LAZARUS, RS 1990: Stress, coping and illness. (In: Friedman, HS ed. 1990: Personality and disease. New York: John Wiley \& Sons.)

MARSHALL, GN; WORTMAN, C; VICKERS, R; KUSULAS, J \& HERVIG, L 1994: The Five-Factor Model of Personality as a Framework for Personality-Health Research. Joumal of Personality and Social Psychology, 67(2): 278-286.

MATZARRO, JD 1980: Behavioural health and Behavioural Medicine: Frontiers for a new health psychology. American Psychologist, 35: 807-817.

MCADAMS, DP 1995: What do we know when we know a person? Joumal of Personality, 63(3): $365-396$.

MCADAMS, DP 1996: Alternative futures for the study of Human Individuality. Journal of Research in Personality, 30: $374-388$.

MCCRAE, RR \& JOHN, OP 1992: An Introduction to the Five-Factor Model and its Applications. Journal of Personality, 60(2): 175-215.

POMERLEAU, OF 1982: A Discourse on Behavioural Medicine: Current Status and Future Trends. Journal of Consulting and Clinical Psychology, 50(6): 1030-1039.

PRIOR, A 1994: Irritable Bowel Syndrome. Medicine International: South African Edition, Part 3 of 4, 22(8): $327-332$.

SMITH, TW \& WILLIAMS, PG 1992: Personality and Health: Advantages and Limitations of the Five-Factor Model. Journal of Personality, 60(2): $395-423$.
STONE, SV \& COSTA, PT Jr 1990: Disease-prone personality or distress-prone personality? The role of neuroticism in coronary heart disease. (In: Friedman, HS ed. 1990: Personality and disease. New York: John Wiley \& Sons.)

STRUMPFER, DJW 1990: Salutogenesis: A new paradigm. S. Airr. J Psychol. 20(4): 265 - 276.

SULS, J \& RITTENHOUSE, JD 1990: Models of linkages between personality and disease. (In: Friedman, HS ed. 1990: Personality and disease. New York: John Wiley \& Sons.)

TEMOSHOK, L 1990: On attempting to articulate the biopsychosocial model; psychological-psychophysiological homeostasis. (In: Friedman, HS ed. 1990: Personality and disease. New York: John Wiley \& Sons.)

THORESEN, CE \& EAGLESTON, JR 1985: Counselling for Health. The Counselling Psychologist, 13(1): 15-87.

VICKERS, R Jr; CONWAY, TL \& HERVIG, LK 1990: Demonstration of Replicable Dimensions of Health Behaviours. Preventive Medicine, 19:377 - 401.

WALKER, EA; ROY-BYRNE, PP \& KATON, WJ 1990: Irritable Bowel Syndrome and Psychiatric Illness. Am. Journal. Psychiatry, 147(5): 565 - 572.

WALKER, EA; ROY-BYRNE, PP; KATON, WJ; LI, L; AMOS, D \& JIRANEK, G 1990: Psychiatric illness and irritable bowel syndrome: A comparison with inflammatory bowel disease. American Journal of Psychiatry, $147(12), 1656-1661$

WHITEHEAD, W 1988: Perception of Gastrointestinal Events. (In: Hellhammer, D \& Weiner, $H$ eds. 1988: Neurobiological approaches to Human Disease. Toronto: Hans Huber.

WHITEHEAD, WE \& BOSMAJIAN, LS 1982: Behavioural Medicine Approaches to Gastrointestinal Disorders. Journal of Consulting and Clinical Psychology, 50(6): 972-983. 